\title{
PERLINDUNGAN HUKUM BAGI KORBAN YANG DIRUGIKAN AKIBAT PENYEBARAN BERITA BOHONG
}

\author{
Erna Tri Rusmala Ratnawati \\ Fakultas Hukum Universitas Widya Mataram \\ nDalem Mangkubumen K'T III/237Yogyakarta \\ ernatr2015@gmail.com
}

\begin{abstract}
Abstrak
Rumusan Masalah dalam penelitian ini adalah apakah wawancara Anji dengan Hadi Pranoto terkait dengan vaksin COVID-19 yang viral memenuhi unsur tindak pidana penyebaran hoax (berita bohong) ? Bagaimana perlindungan hukum bagi korban yang telah dirugikan akibat penyebaran berita bohong (hoax)? Penelitian ini merupakan penelitian deskriptif normatif dengan menggunakan pendekatan undang-undang (statute approach), dan pendekatan konseptual (conceptual approach) dengan metode analisis diskriptif kualitatif. Hasil analisis terhadap rumusan masalah adalah berita viral wawancara Anji dengan Hadi Pranoto memenuhi unsur tindak pidana penyebaran hoax (berita bohong) yang dapat dijerat melalui Pasal 28 (1) UU Nomor 11 Tahun 2008 Tentang ITE, namun demikian UU ITE bukanlah satu-satunya dasar hukum yang dapat dipakai untuk menjerat orang yang menyebarkan hoax, karena Pasal 28 (1) UU ITE hanya mengatur penyebaran berita bohong dan menyesatkan yang mengakibatkan kerugian konsumen dalam transaksi elektronik saja, sehingga perlu di juntokan UU Nomor 1 Tahun 1946. Perlindungan hukum bagi korban yang telah dirugikan akibat penyebaran informasi hoax, selain pertanggungjawaban pidana maka korban yang telah dirugikan akibat penyebaran informasi hoax tersebut dapat mengajukan perlindungan hukum melalui gugatan perdata melalui gugatam wanprestasi atau perbuatan melawan hukum berdasarkan KUH Perdata maupun berdasarkan Pasal 38 UU ITE.
\end{abstract}

Kata Kunci : Berita Bohong, Korban, Perlindungan Hukum

\begin{abstract}
The problem formulation of this research is to determine whether Anji's interview with Mr. Hadi Pranoto on the subject of Corona Virus Disease (COVID-19), which viral on the media, meets the criteria of hoax spreading criminal act. Secondly, it is to determine the legal protection for the victim of this hoax. This research is a descriptive-normative study using statute and conceptual approach with descriptive qualitative analysis. The analysis result of the problem formulation is that the viral interview meets the criteria of hoax spreading criminal act, which can be charged with Article 28(1) of UndangUndang Nomor 11 Tabun 2008 concerning information and electronic transaction. However, this law is not the only legal basis that can be used to prosecute hoax spreaders. Because it is only ruling about hoax spreading that causing losses of consumers in an electronic transaction, Thus it is imperative to include Undang-Undang Nomor 1 Tabun 1946 in the charge. For the second problem in terms of legal protection, besides the criminal accountability for the perpetrator, the victims who have been harmed due to the spread of the hoax can apply for a civil lawsuit of an act against the law based on Kitab Undang-Undang Hukum Perdata Article 38 of Undang-Undang Nomor 11 Tabun 2008.
\end{abstract}

Key Words: Hoax, Victim, Legal Protection.

\section{A. Pendahuluan}

Beberapa waktu yang lalu, masyarakat dihebohkan dengan berita viral wawancara Anji dengan Hadi Pranoto, yang mana Anji menyebut Hadi Pranoto sebagai profesor dan ahli mikrobiologi, yang mengklaim menemukan obat atau herbal antibodi Covid-19, dan telah menyembuhkan ribuan pasien dalam waktu 2-3 hari bahkan juga mengaku menyalurkan obatnya ke RS Darurat Wisma Atlet. Pernyataan tersebut telah dibantah Kepala Pusat 
Kesehatan TNI AD Mayor Jenderal Tugas Ratmono yang menyatakan bahwa RS Darurat Wisma Atlet tidak pernah menggunakan obat herbal yang diproduksi Hadi Pranoto untuk pasien Covid-19, demikian pula IDI juga menyatakan Hadi Pranoto bukan anggota kelompok pakar mikrobiologi. ${ }^{1}$

Tayangan tersebut dianggap meresahkan masyarakat dan memberikan informasi yang tidak akurat sehingga mendapat banyak tentangan oleh akademisi, ilmuwan, ikatan dokter Indonesia (IDI) dan berpotensi menimbulkan kegaduhan dan polemik di tengah masyarakat. Berdasarkan hal tersebut maka Ketua Umum Cyber Indonesia, Muannas Alaidid membuat laporan dan telah diterima oleh Polda Metro Jaya dengan nomor LP/4538/VIII/YAN.2.5/2020/SPKT PMJ, dengan pasal yang dipersangkakan adalah Pasal 28 ayat (1) Undang-Undang Nomor 11 Tahun 2008 tentang Informasi dan Transaksi Elektronik (ITE) Jo Pasal 45A Undang-Undang RI Nomor 19 tahun 2016 dan atau Pasal 14 dan Pasal 15 Undang-Undang RI Nomor 1 Tahun 1946 tentang Peraturan Hukum Pidana. ${ }^{2}$

Kemristek mengimbau agar masyarakat berhati-hati dengan produk herbal yang belum terbukti kebenarannya untuk dicek ke sumber resmi terpercaya seperti Kementerian Kesehatan atau Badan Pengawas Obat dan Makanan. Karena setiap klaim yang disebutkan harus melewati kaidah penelitian yang benar dan melakukan uji klinis sesuai protokol yang disetujui oleh BPOM. ${ }^{3}$

Perkembangan dan kemajuan Teknologi Informasi yang demikian pesat telah menyebabkan perubahan kegiatan kehidupan manusia dalam berbagai bidang yang secara langsung telah memengaruhi lahirnya bentuk-bentuk perbuatan hukum baru. ${ }^{4}$ Kemajuan teknologi informasi dan komunikasi, penggunaan internet khususnya media online sangat diminati masyarakat Indonesia, karena penggunaan media online lebih memudahkaan masyarakat untuk mencari informasi maupun berita dengan efektif dan efisien. Kemajuan teknologi informasi komunikasi tidak hanya memberikan dampak yang positif tetapi juga memberikan dampak negatif. Melalui teknologi informasi ini maka setiap orang dengan mudah memproduksi informasi, dan informasi tersebut dengan cepat tersampaikan melalui media sosial seperti facebook, twitter, Instagram, whatsapp dan lain sebagainya. Namun demikian informasi yang dikeluarkan baik orang perseorangan maupun badan hukum melalui media

1 https://metro.tempo.co/read/1372173/dituding-sebarkan-berita-bohong-musisi-anji-dilaporkan-kepolisi/full\&view $={ }_{\mathrm{ok}}$, Tempo, diakses senin, 3 Agustus 2020.

${ }^{2}$ Ibid.

3 https://tekno.tempo.co/read/1372089/ramai-obat-herbal-covid-19-hadi-pranoto-ini-tanggapankemristek/full\&view $=$ ok diakses, senin 3 agustus 2020

4 Bagian menimbang UU Nomor 11 Tahun 2011 Tentang ITE 
sosial dan elektronik seringkali berisikan informasi yang tidak akurat, informasi bohong (boax), mengandung fitnah, menyebar kebencian, menyerang pihak lain, membuat orang menjadi takut, terancam yang dapat merugikan pihak lain atau merusak reputasi dan menimbulkan kerugian materi.

Saat ini media sosial dengan cepat menyebarkan informasi kepada masyarakat, apabila tidak teliti dan hati-hati maka masyarakat akan terpengaruh dan menelan mentah-mentah informasi yang mereka dapatkan dari berita hoax yang banyak berseliweran yang kadangkadang bahkan sulit dibedakan karena dikemas dengan bahasa ilmiah dan menyakinkan sedemikian rupa. Kapan suatu berita memenuhi unsur hoax sehingga dapat memenuhi unsur tindak pidana atau dapat menimbulkan gugatan perdata karena telah merugikan orang lain.

Menurut pandangan psikologis, ada dua faktor yang dapat menyebabkan seseorang cenderung mudah percaya pada hoax. Orang lebih cenderung percaya hoax jika informasinya sesuai dengan opini atau sikap yang dimiliki. ${ }^{5}$ Secara alami perasaan positif akan timbul dalam diri seseorang jika opini atau keyakinannya mendapat afirmasi sehingga cenderung tidak akan mempedulikan apakah informasi yang diterimanya benar atau salah dan bahkan mudah saja mereka untuk menyebarkan kembali informasi tersebut. Hal ini semakin diperparah apabila si penyebar hoax kurang memiliki pengetahuan dalam memanfaatkan internet guna mencari informasi lebih dalam atau sekadar untuk cek dan ricek fakta.

Berita hoax semakin sulit dibendung walaupun pemerintah telah memblokir situs yang mengandung konten negatif, namun setiap harinya pula berita hoax terus bermunculan, hal ini mungkin karena kasus pemblokiran tersebut tidak diikuti dengan proses penegakan hukum di pengadilan sehingga para penyebar hoax masih berkeliaran dan tidak merasa jera. Berdasarkan permasalahan di atas penulis merumuskan dua permasalahan yaitu, apakah berita viral wawancara Anji dengan Hadi Pranoto memenuhi unsur tindak pidana penyebaran hoax (berita bohong)? dan bagaimana perlindungan hukum bagi korban yang telah dirugikan akibat penyebaran informasi boax?

\section{B. Telaah Konsep}

\section{Informasi Elektonik}

${ }^{5}$ Respati, S. (2017, January 23). Mengapa Banyak Orang Mudah Percaya Berita "Hoax"? Kompas.com. Retrieved fromhttp://nasional.kompas.com/read/2017/01/23/18181951/mengapa.banyak.orang.mudah.percaya.berita .hoax. 
Informasi Elektronik adalah satu atau sekumpulan data elektronik, termasuk tetapi tidak terbatas pada tulisan, suara, gambar, peta, rancangan, foto, electronic data interchange (EDI), surat elektronik (electronic mail), telegram, teleks, telecopy atau sejenisnya, huruf, tanda, angka, Kode Akses, simbol, atau perforasi yang telah diolah ${ }^{6}$

Dokumen Elektronik adalah setiap Informasi Elektronik yang dibuat, diteruskan, dikirimkan, diterima, atau disimpan dalam bentuk analog, digital, elektromagnetik, optikal, atau sejenisnya, yang dapat dilihat, ditampilkan, dan/atau didengar melalui Komputer atau Sistem Elektronik, termasuk tetapi tidak terbatas pada tulisan, suara, gambar, peta, rancangan, foto atau sejenisnya, huruf, tanda, angka, Kode Akses, simbol atau perforasi yang memiliki makan atau arti atau dapat dipahami oleh orang yang mampu memahaminya. ${ }^{7}$

Informasi Elektronik dan/atau Dokumen Elektronik dan/atau hasil cetaknya merupakan alat bukti hukum yang sah. Informasi Elektronik dan/atau Dokumen Elektronik dan/atau hasil cetaknya sebagaimana dimaksud pada ayat (1) merupakan perluasan dari alat bukti yang sah sesuai dengan Hukum Acara yang berlaku di Indonesia. ${ }^{8}$

\section{Pengertian Hoax}

Hoax adalah usaha untuk menipu atau mengakali pembaca/pendengarnya untuk mempercayai sesuatu, padahal sang pencipta berita palsu tersebut tahu bahwa berita tersebut adalah palsu. Salah satu contoh pemberitaan palsu yang paling umum adalah mengklaim sesuatu barang atau kejadian dengan suatu sebutan yang berbeda dengan barang/kejadian sejatinya. Suatu pemberitaan palsu berbeda dengan misalnya pertunjukan sulap; dalam pemberitaan palsu, pendengar/penonton tidak sadar sedang dibohongi, sedangkan pada suatu pertunjukan sulap, penonton justru mengharapkan supaya ditipu' Hoax dalam Bahasa Indonesia berarti berita bohong, informasi palsu, atau kabar dusta. Sedangkan menurut kamus bahasa Inggris, hoax artinya olok-olok, cerita bohong, dan memperdayakan alias menipu. $^{10}$

Hoax diterjemahkan dalam bahasa Indonesia berarti berita bohong. Istilah hoax tidak dikenal dalam peraturan perundang-undangan Indonesia, tetapi ada beberapa peraturan yang mengatur tentang berita bohong salah satumya dalam Pasal 28 ayat (1) Undang-Undang

\footnotetext{
${ }^{6}$ Pasal 1 Angka 1 UU Nomor 11 Tahun 2008 Tentang Informasi Dan Transaksi Elektronik

${ }^{7}$ Pasal 1 Angka 4 UU Nomor 8 Tahun 2008 Tentang Informasi Dan Transaksi Elektronik

8 Pasal 5 ayat 1 dan 2 UU Nomor 8 Tahun 2008 Tentang Informasi Dan Transaksi Elektronik

9 Wikipedia.(n.d.).Pemberitaanpalsu.https://mti.binus.ac.id/2017/07/03/penyalahgunaan-informasiberitahoax-di-media-sosial/

${ }^{10}$ Christiany Juditha, 2018, Interaksi Komunikasi Hoax di Media Sosial serta Antisipasinya, Jurnal Pekommas, Vol. 3 No. 1, hal. 31.
} 
Nomor 11 Tahun 2008 tentang Informasi dan Transaksi Elektronik (ITE). UU ITE tidak menjelaskan apa yang dimaksud dengan "berita bohong dan menyesatkan", tetapi, apabila dicermati lagi ternyata pasal 28 ayat (1) UU ITE khusus mengatur mengenai hoax (berita bohong) yang mengakibatkan kerugian konsumen dalam transaksi elektronik.

Bagaimana seandainya penyebaran berita bohong tersebut tidak mengakibatkan kerugian konsumen dalam transaksi elektronik itu yang juga masih sering menjadi perdebatan. Hal ini sejalan dengan hasil riset yang menyatakan bahwa Efektivitas Undang-Undang Republik Indonesia Nomor19 tahun 2016 Tentang Informasi dan Transaksi Elektronik terhadap penanganan tindak pidana penyebaran berita bohong (hoax) belum efektif dan belum dapat mengakomodir sepenuhnya kasus-kasus penyebaran berita bohong (hoax), masih diperlukan undang-undang lain yaitu Undang-Undang Republik Indonesia Nomor 1 Tahun 1946 Tentang Peraturan Hukum Pidana dalam penanganan berita bohong (hoax) dan belum ada undang-undang yang mengatur tentang pertanggungjawaban pidana akan perbuatan penyebaran berita bohong (hoax) saja ${ }^{11}$

\section{Pertanggungjawaban Pidana}

Pertanggungjawaban pidana dalam bahasa asing disebut sebagai criminal liability. Definisi pertanggungjawaban pidana yaitu dapat dipersalahkan seseorang karena perbuatan melawan hukum yang dilakukannya, sehingga ia dapat dipertanggungjawabkan pidana (verwijbaarbeid) $)^{12}$. Pertanggungjawaban pidana pada dasarnya dapat dipertanggungjawabkan kepada diri seorang pelaku tindak pidana, tetapi harus memenuhi 4 (empat) unsur persyaratan sebagai berikut: ${ }^{13}$

a. Ada suatu tindakan (commission atau omission) oleh si pelaku;

b. Yang memenuhi rumusan-rumusan delik dalam Undang-undang;

c. Tindakan itu bersifat melawan hukum;

d. Pelakunya harus bisa dipertanggungjawabkan.

\section{Unsur-Unsur Tindak Pidana Berita Bohong}

a. Dalam Kitab Undang-Undang Hukum Pidana (KUHP )

Pasal 390 Kitab Undang-Undang Hukum Pidana (KUHP) mengatur tindak pidana "menyiarkan kabar bohong", yang berbunyi "Barang siapa dengan maksud hendak menguntungkan diri sendiri atau orang lain dengan melawan hak

\footnotetext{
${ }^{11}$ Hendral Veno, Efa Laela Fakhriah, 2019, Efektivitas Undang-Undang Republik Indonesia Nomor 19 Tabun 2016 Tentang Informasi Dan Transaksi Elektronik Terbadap Penanganan, Scientia Regend Volume I, No1 Agustus,

12 I Ketut Mertha et. al., 2016, Buku Ajar Hukum Pidana Fakultas Hukum Universitas Udayana, Denpasar, hal.145.

${ }^{13}$ Romli Atmasasmita, 2000, Perbandingan Hukum Pidana, Mandar Maju, Bandung, hal 67
} 
menurunkan atau menaikkan harga barang dagangan, fonds atau surat berharga uang dengan menyiarkan kabar bohong, dihukum penjara selama-lamanya dua tahun delapan bulan".

Menurut R.Soesilo, terdakwa hanya dapat dihukum dengan Pasal 390 KUHP, apabila ternyata bahwa kabar yang disiarkan itu adalah kabar bohong. Yang dipandang sebagai kabar bohong, tidak saja memberitahukan suatu kabar yang kosong, akan tetapi juga menceritakan secara tidak betul tentang suatu kejadian. ${ }^{14}$

b. Dalam Undang-Undang Nomor 1 Tahun 1946 Tentang Peraturan Hukum

\section{Pidana}

Pasal 14 dan Pasal 15 Undang-Undang Nomor 1 Tahun 1946 tentang Peraturan Hukum Pidana juga mengatur mengenai berita bohong yakni:

Pasal 14 ayat (1) Barangsiapa, dengan menyiarkan berita atau pemberitahuan bohong, dengan sengaja menerbitkan keonaran dikalangan rakyat, dihukum dengan hukuman penjara setinggi-tingginya sepuluh tahun.

Pasal 14 ayat(2) Barangsiapa menyiarkan suatu berita atau mengeluarkan pemberitahuan yang dapat menerbitkan keonaran dikalangan rakyat, sedangkan ia patut dapat menyangka bahwa berita atau pemberitahuan itu adalah bohong, dihukum dengan penjara setinggi-tingginya tiga tahun.

Pasal 15 Barangsiapa menyiarkan kabar yang tidak pasti atau kabar yang berkelebihan atau yang tidak lengkap, sedangkan ia mengerti setidak-tidaknya patut dapat menduga bahwa kabar demikian akan atau sudah dapat menerbitkan keonaran dikalangan rakyat, dihukum dengan hukuman penjara setinggi, tingginya dua tahun

\section{c. Dalam UU ITE}

Terkait dengan penyebaran berita bohong (hoax) ketetuan pidana diatur dalam pasal berikut :

1) Pasal 28 ayat (1) Undang-Undang Nomor 11 Tahun 2008 tentang Informasi dan Transaksi Elektronik (ITE) mengatur ketentuan tindak pidana penyebaran berita bohong "Setiap Orang dengan sengaja dan tanpa hak menyebarkan berita bohong dan menyesatkan yang mengakibatkan kerugian konsumen dalam Transaksi Elektronik"

${ }_{14}$ R Soesilo, Kitab Undang-undang Hukum Pidana serta Komentar-komentarnya Lengkap Pasal demi Pasal, Politea, Bogor, 1998, hal. 269 
2) Pasal 45A Undang-Undang Nomor 19 tahun 2016, Setiap Orang yang dengan sengaja dan tanpa hak menyebarkan berita bohong dan menyesatkan yang mengakibatkan kerugian konsumen dalam Transaksi Elektronik sebagaimana dimaksud dalam Pasal 28 ayat (1) Undang-Undang Nomor 11 Tahun 2008 tentang Informasi dan Transaksi Elektronik (ITE) dipidana dengan pidana penjara paling lama 6 (enam) tahun dan/atau denda paling banyak Rp1.000.000.000,00 (satu miliar rupiah).

\section{Pertanggungjawaban Perdata}

Menurut Kamus Besar Bahasa Indonesia (KBBI) tanggung jawab adalah kewajiban menanggung segala sesuatunya (bila terjadi apa-apa boleh dituntut, dipersalahkan dan diperkarakan dan sebagainya). ${ }^{15}$ Menurut Black's Law Dictionary, tanggung jawab (liability) mempunyai tiga arti, antara lain:

a. An obligation one is bound in law or justice to perform.

b. Condition of being responsible for a possible or actual loss.

c. Condition which creates a duty to perform an act immediately $o$ in the future.

Tanggung jawab hukum (legal liability) menurut Black's Law Dictionary mempunyai arti: "Liability which court recognize and enforce as between parties litigant." Ada dua istilah yang menunjuk pada pertanggungjawaban dalam kamus hukum, yaitu liability dan responsibility. Liability merupakan istilah hukum yang luas yang menunjuk hampir semua karakter risiko atau tanggung jawab, yang pasti, yang bergantung atau yang mungkin meliputi semua karakter hak dan kewajiban secara aktual atau potensial seperti kerugian, ancaman, kejahatan, biaya atau kondisi yang menciptakan tugas untuk melaksanakan undang-undang. Responsibility berarti hal yang dapat dipertanggungjawabkan atas suatu kewajiban, dan termasuk putusan, ketrampilan, kemampuan dan kecakapan meliputi juga kewajiban bertanggung jawab atas undang-undang yang dilaksanakan. Dalam pengertian dan penggunaan praktis, istilah liability menunjuk pada pertanggungjawaban hukum, yaitu tanggung gugat akibat kesalahan yang dilakukan oleh subyek hukum, sedangkan istilah responsibility menunjuk pada pertanggungjawaban politik. ${ }^{16}$

Apabila seseorang dirugikan karena perbuatan orang lain, sedang diantara mereka itu tidak terdapat sesuatu perjanjian(hubungan hukum perjanjian), maka berdasarkan undang undang juga timbul atau terjadi hubungan hukum antara orang tersebut yang menimbulkan

15 https://www.kbbi.web.id/

${ }^{16}$ Ridwan H.R., Hukum Administrasi Negara, Raja Grafindo Persada, Jakarta, 2006, hal. 335-337. 
kerugian itu. ${ }^{17} \mathrm{Hal}$ ini diatur dalam pasal 1365 KUHPerdata, sebagai berikut : "Tiap perbuatan melanggar hukum yang membawa kerugian pada orang lain, mewajibkan orang yang karena salahnya menerbitkan kerugian itu, mengganti kerugian tersebut". Adapun yang dimaksud dengan perbuatan melanggar hukum adalah perbuatan melawan hukum yang dilakukan oleh seseorang yang karena salahnya telah menimbulkan kerugian bagi orang lain.

Dalam ilmu hukum dikenal 3 (tiga) kategori dari perbuatan melawan hukum, yaitu sebagai berikut: ${ }^{18}$

a. Perbuatan melawan hukum karena kesengajaan

b. Perbuatan melawan hukum tanpa kesalahan (tanpa unsur kesengajaan maupun kelalaian)

c. Perbuatan melawan hukum karena kelalaian

Adapun model tanggungjawab hukum adalah sebagai berikut: ${ }^{19}$

a. Tanggung jawab dengan unsur kesalahan (kesengajaan dan kelalaian) sebagaimana terdapat dalam pasal1365 KUHPerdata.

b. Tanggung jawab dengan unsur kesalahan khususnya kelalaian sebagaimana terdapat dalam pasal 1366KUHPerdata.

c. Tanggung jawab mutlak (tanpa kesalahan) sebagaimana terdapat dalam pasal 1367 KUHPerdata.

Pengertian perbuatan melawan hukum menjadi lebih luas dengan adanya keputusan Hoge Raad tanggal 31 Januari 1919, yaitu bahwa perbuatan melawan hukum (onrechmatige daad) diartikan suatu perbuatan atau kealpaan, yang atau bertentangan dengan hak orang lain, atau bertentangan dengan kewajiban hukum si pelaku atau bertentangan, baik dengan kesusilaan baik, pergaulan hidup terhadap orang lain atau benda, sedang barang siapa karena salahnya sebagai akibat dari perbuatannya itu telah mendatangkan kerugian pada orang lain,berkewajiban membayar ganti kerugian". ${ }^{20}$

\section{Metode Penelitian}

17 AZ Nasution, Hukum Perlindungan Konsumen, cet.2, Diapit Media, Jakarta, 2002, hal.77.

${ }^{18}$ Munir Fuady, Perbuatan Melawan Hukum, cet.1, CitraAditya Bakti, Bndung, 2002, hal.3.

19 Ibid.

${ }^{20}$ M.A. Moegni Djojodirdjo, PerbuatanMelawan Hukum, cet.2, Pradnya Paramita, Jakarta, hal 25-26. 
Penelitian ini merupakan penelitian hukum ${ }^{21}$ yang menggunakan beberapa pendekatan untuk dapat menjawab permasalahan yang diteliti yaitu pendekatan undangundang (statute approach), dan pendekatan konseptual (conceptual approach). Pendekatan perundang-undang digunakan untuk dapat mengkaji secara mendalam berbagai peraturan yang berkaitan dengan Informasi dan transaksi Elektronik terkait dengan berita hoax. Pendekatan konseptual digunakan untuk dapat memahami tentang pertanggungjawaban pidana dan perdata dampak dari berita hoax. Penelitian ini menggunakan metode analisis isi (content analysis) adalah penelitian yang bersifat pembahasan mendalam terhadap isi suatu informasi tertulis atau tercetak dalam media massa yaitu mencatat pesan secara sistematis, kemudian diberi interpretasi. ${ }^{22}$

\section{Pembahasan}

\section{Unsur-Unsur Yang Harus Dipenuhi Agar Penyebaran Hoax Termasuk Tindak Pidana (analisis berita viral wawancara Anji dengan Hadi Pranoto)}

Penyebaran informasi atau berita melalui media online tidak hanya dilakukan oleh situs berita yang sudah dikenal oleh masyarakat saja, melainkan siapa saja pengguna internet dapat menyebarkan informasi atau berita melalui media online. Hal ini mengakibatkan setiap orang dapat berekspresi dan bebas menyebarkan informasi atau berita melalui media online yang dimiliki. Berdasarkan hal tersebut apabila tidak hati-hati maka penggunaan media online justru mengakibatkan munculnya perbuatan hukum yang mengakibatkan timbulnya tindak pidana ataupun melanggar hak keperdataan.

Pemberitaan bohong (hoax) diolah sedemikian rupa agar menarik minat pembaca, sehingga para warganet tidak menyadari itu sebagai berita atau informasi hoax dan justru saling berkomentar untuk membahas dengan versi opininya masing-masing sehingga menambah rumit dan bias.

Adapun rumusan delik yang mengatur tentang berita bohong (hoax) melalui media elektronik atau online telah diatur dalam Pasal 28 ayat (1) yang menyatakan bahwa Setiap Orang dengan sengaja dan tanpa hak menyebarkan berita bohong dan menyesatkan yang mengakibatkan kerugian konsumen dalam Transaksi Elektronik. Apabila diperhatikan ketentuan Pasal 28 ayat (1) tersebut mengandung unsur setiap orang, dengan sengaja dan

${ }^{21}$ F Sugeng Istanto, 2007, Metode Penelitian, Raja Grafindo Persada, Jakarta, hal 29

22 https://www.dosenpendidikan.co.id/analisis-isi/ 
tanpa hak, menyebarkan berita bohong dan menyesatkan, mengakibatkan kerugian konsumen, dalam Transaksi Elektronik.

Dikaitkan dengan kasus Anji, bahwa unsur setiap orang sudah terpenuhi dalam hal ini adalah Anji dan Hadi Pranoto kedua-duanya dapat dijerat hukum karena kedua-duanya melakukan perbuatan yang sama yaitu menyebarkan berita bohong melalui proses wawancara yang dilakukan melalui chanel youtube milik Anji, hanya bedanya Hadi Pranoto adalah sebagai sumber informasi sedangkan Anji adalah sebagai yang memberikan fasilitas media dan yang mewawancarai. Kedua-duanya berperan dalam melakukan perbuatan pidana, karena tanpa peran keduanya tidak mungkin perbuatan hukum itu terjadi. Unsur sengaja juga terpenuhi karena tidak mungkin wawancara itu tanpa persiapan terlebih dahulu.

Demikian pula unsur melawan hak juga terpenuhi karena Hadi pranoto menyampaikan informasi yang melawan hukum yaitu informasi bohong tidak sesuai dengan fakta dan ketentuan hukum yang berlaku. Unsur menyebarkan berita bohong dan menyesatkan juga terpenuhi karena informasi terkait dengan penemuan obat atau herbal antibodi Covid-19, dan telah menyembuhkan ribuan pasien dalam waktu 2-3 hari ternyata tidak benar atau bohong dan tentunya juga menyesatkan masyarakat. Demikian juga unsur merugikan konsumen juga terpenuhi karena berdasarkan pengakuan dari Hadi Pranata bahwa obat tersebut telah disebarkan ke pelosok daerah, itu artinya sudah merugikan masyarakat selaku konsumen. Unsur adanya transaksi elektronik juga terpenuhi karena setidaknya dengan adanya wawancara tersebut dengan harapan bahwa produknya laku dan dapat diperjual belikan.

Ancaman pidana pelanggaran Pasal 28 ayat (1) diatur dalam Pasal 45A ayat (1) Setiap Orang yang dengan sengaja dan tanpa hak menyebarkan berita bohong dan menyesatkan yang mengakibatkan kerugian konsumen dalam Transaksi Elektronik sebagaimana dimaksud dalam Pasal 28 ayat (1) dipidana dengan pidana penjara paling lama 6 (enam) tahun dan/atau denda paling banyak Rp1.000.000.000,00 (satu miliar rupiah).

Namun demikian yang menjadi persoalan berikutnya adalah bagaimana apabila ternyata informasi atau berita bohong itu tidak memenuhi unsur mengakibatkan kerugian konsumen dan tidak melakukan transaksi elektronik. Sesuai dengan asas legalitas maka untuk dapat menjadi tindak pidana harus memenuhi semua unsur-unsur pasal yang diatur dalam undangundang, dengan demikian apabila tidak terpenuhi maka dapat dijuntokan dengan pasal lain agar dapat terpenuhi unsurnya. Selain dalam Pasal 28 ayat (1) UUITE, Unsur-Unsur Tindak Pidana menyiarkan kabar bohong juga diatur dalam Pasal 390 Kitab Undang-Undang Hukum 
Pidana (KUHP) yang menyatakan "Barang siapa dengan maksud hendak menguntungkan diri sendiri atau orang lain dengan melawan hak menurunkan atau menaikkan harga barang dagangan, fonds atau surat berharga uang dengan menyiarkan kabar bohong, dihukum penjara selama-lamanya dua tahun delapan bulan”.

Demikian juga Pasal 14 dan Pasal 15 Undang-Undang Nomor 1 Tahun 1946 Tentang Peraturan Hukum Pidana juga mengatur mengenai berita bohong yakni: Pasal 14 ayat (1) Barangsiapa, dengan menyiarkan berita atau pemberitahuan bohong, dengan sengaja menerbitkan keonaran dikalangan rakyat, dihukum dengan hukuman penjara setinggitingginya sepuluh tahun. Pasal 14 ayat (2)Barangsiapa menyiarkan suatu berita atau mengeluarkan pemberitahuan yang dapat menerbitkan keonaran dikalangan rakyat, sedangkan ia patut dapat menyangka bahwa berita atau pemberitahuan itu adalah bohong, dihukum dengan penjara setinggi-tingginya tiga tahun. Pasal 15 Barangsiapa menyiarkan kabar yang tidak pasti atau kabar yang berkelebihan atau yang tidak lengkap, sedangkan ia mengerti setidak-tidaknya patut dapat menduga bahwa kabar demikian akan atau sudah dapat menerbitkan keonaran dikalangan rakyat, dihukum dengan hukuman penjara setinggi, tingginya dua tahun.

Keberadaan KUHP dan Undang-Undang Nomor 1 Tahun 1946 Tentang Peraturan Hukum Pidana yang mengatur tentang berita bohong ini adalah sebagai ketentuan umum (lex generali) yang dapat melengkapi ketentuaan yang ada dalam UU ITE, karena ketentuan yang ada dalam ITE adalah terbatas kepada informasi elektronik atau online.

\section{Perlindungan Hukum Bagi Korban Yang Telah Dirugikan Akibat Penyebaran Informasi hoax}

Selain pertanggungjawaban pidana seperti yng sudah dijelaskan dalam pokok bahasan yang pertama diatas maka korban yang telah dirugikan akibat penyebaran informasi hoax tersebut dapat mengajukan perlindungan hukum melalui gugatan perdata. Pihak-pihak yang telah dirugikan sebagai dampak tindak pidana yang merugikan secara materiil tentunya dapat mengajukan gugatan secara perdata agar kerugian yang dideritanya dapat dikembalikan sesuai dengan ketentuan di dalam hukum perdata maupun acara perdata pada umumnya sebaga lex generalie. Gugatan secara perdata dapat dilakukan baik atas dasar wanprestasi maupun perbuatan melawan hukum. Apabila seseorang dirugikan karena perbuatan orang lain, sedang diantara mereka itu tidak terdapat sesuatu perjanjian (hubungan hukum perjanjian), maka berdasarkan undang undang juga timbul atau terjadi hubungan hukum antara orang tersebut 
yang menimbulkan kerugian itu. Hal ini diatur dalam Pasal 1365 KUHPerdata, sebagai berikut :"Tiap perbuatan melanggar hukum yang membawa kerugian pada orang lain, mewajibkan orang yang karena salahnya menerbitkan kerugian itu,mengganti kerugian tersebut".

Berdasarkan Pasal 1365 Kitab Undang-Undang Hukum Perdata (KUHPerdata), bahwa unsur perbuatan melawan hukum adalah Tiap perbuatan, yang melanggar hukum, kesalahan, membawa kerugian kepada orang lain, ada hubungan sebab akibat antara kerugian dan perbuatan;

Adanya perbuatan artinya bahwa untuk terjadinya perbuatan melawan hukum maka terlebih dahulu pasti diawali dengan adanya perbuatan hukum, dan unsur perbuatan ini adalah termasuk dalam kategori perbuatan melawan hukum. Perbuatan melawan hukum berarti adanya perbuatan atau tindakan dari pelaku yang melanggar/melawan hukum. Pengertian melanggar hukum ditafsirkan sempit, yakni hanya hukum tertulis saja, yaitu undang-undang. Jadi seseorang atau badan hukum hanya bisa digugat kalau dia melanggar hukum tertulis (undang-undang) saja.Tapi sejak tahun 1919, ada putusan Mahkamah Agung Belanda dalam kasus Arrest Cohen-Lindenbaum (H.R. 31 Januari 1919), yang kemudian telah memperluas pengertian melawan hukum tidak hanya terbatas pada undang-undang (hukum tertulis saja) tapi juga hukum yang tidak tertulis, sebagai berikut: ${ }^{23}$ :

a. Melanggar Undang-Undang, artinya perbautan yang dilakukan jelas-jelas melanggar undang-undang.

b. Melanggar hak subjektif orang lain, artinya jika perbuatan yang dilakukan telah melanggar hak-hak orang lain yang dijamin oleh hukum (termasuk tapi tidak terbatas pada hak yang bersifat pribadi, kebebasan, hak kebendaan, kehormatan, nama baik ataupun hak perorangan lainnya.

c. Bertentangan dengan kewajiban hukum si pelaku, artinya kewajiban hukum baik yang tertulis maupun yang tidak tertulis, termasuk hukum publik.

d. Bertentangan dengan kesusilaan, yaitu kaidah moral (Pasal 1335 Jo Pasal 1337 KUHPerdata)

e. Bertentangan dengan sikap kehati-hatian yang sepatutnya dalam masyarakat. Kriteria ini bersumber pada hukum tak tertulis (bersifat relatif). Yaitu perbuatan yang dilakukan bertentangan dengan sikap yang baik/kepatutan dalam masyarakat untuk memperhatikan kepentingan orang lain.

${ }^{23}$ Wirjono Projodikoro, 1960, Perbuatan Melanggar Hukum, Sumu,r Bandung, hal.51. 
Unsur berikutnya adalah adalah unsur kesalahan. Kesalahan ini ada 2 (dua), bisa karena kesengajaan atau karena kealpaan. Kesengajaan maksudnya ada kesadaran yang oleh orang normal pasti tahu konsekuensi dari perbuatannya itu akan merugikan orang lain.Sedang, Kealpaan berarti ada perbuatan mengabaikan sesuatu yang mestinya dilakukan, atau tidak berhati-hati atau teliti sehingga menimbulkan kerugian bagi orang lain ${ }^{24}$ Namun demikian adakalanya suatu keadaan tertentu dapat meniadakan unsur kesalahan, misalnya dalam hal keadaan memaksa (overmacht) atau si pelaku tidak sehat pikirannya (gila).

Unsur berikutnya adalah adanya hubungan sebab akibat antara kerugian dan perbuatan (Hubungan Kausalitas). Maksudnya, ada hubungan sebab akibat antara perbuatan yang dilakukan dengan akibat yang muncul.Misalnya, kerugian yang terjadi disebabkan perbuatan si pelaku atau dengan kata lain, kerugian tidak akan terjadi jika pelaku tidak melakukan perbuatan melawan hukum tersebut.

Selanjutnya adalah Unsur adanya kerugian, Akibat perbuatan pelaku menimbulkan kerugian. Kerugian di sini dibagi jadi 2 (dua) yaitu Materil dan Imateril.Materil misalnya kerugian karena tabrakan mobil, hilangnya keuntungan, ongkos barang, biaya-biaya, dan lainlain.Imateril misalnya ketakutan, kekecewaan, penyesalan, sakit, dan kehilangan semagat hidup yang pada prakteknya akan dinilai dalam bentuk uang.

KUHPerdata tidak mengatur soal ganti kerugian yang harus dibayar karena Perbuatan Melawan Hukum sedang Pasal 1243 KUHPerdata membuat ketentuan tentang ganti rugi karena Wanprestasi. Menurut Yurisprudensi ketentuan ganti kerugian karena wanprestasi dapat diterapkan untuk menentukan ganti kerugian karena Perbuatan Melawan Hukum.

Penyelesaian secara perdata juga telah diatur dalam Pasal 38 UU Nomor 11 Tahun 2008 diatur bahwa setiap orang dapat mengajukan gugatan terhadap pihak yang menyelenggarakan sistem elektronik dan/atau menggunakan teknologi informasi yang menimbulkan kerugian. Demikian juga masyarakat dapat mengajukan gugatan secara perwakilan terhadap pihak yang menyelenggarakan sistem elektronik dan/atau menggunakan teknologi informasi yang berakibat merugikan masyarakat, sesuai dengan ketentuan peraturan perundang-undangan.

Di samping itu dalam Pasal 39 UU Nomor 11 Tahun 2008 bahwa selain penyelesaian gugatan perdata, para pihak dapat menyelesaikan sengketa melalui arbitrase, atau lembaga penyelesaian sengketa alternatif lainnya sesuai dengan ketentuan Peraturan Perundangundangan.

${ }^{24} \mathrm{Ibid}$, hal 52 


\section{E. Kesimpulan}

Berita viral wawancara Anji dengan Hadi Pranoto memenuhi unsur tindak pidana penyebaran hoax (berita bohong) yang dapat dijerat melalui Pasal 28 UU Nomor 11 Tahun 2008 Tenyang ITE, namun demikian UU ITE bukanlah satu-satunya dasar hukum yang dapat dipakai untuk menjerat orang yang menyebarkan hoax atau berita bohong ini karena UU ITE hanya mengatur penyebaran berita bohong dan menyesatkan yang mengakibatkan kerugian konsumen dalam transaksi elektronik saja dan perlu di jontokan dengan KUHP maupun UU 1/1946. Keberadaan KUHP dan Undang-Undang Nomor 1 Tahun 1946 Tentang Peraturan Hukum Pidana yang mengatur tentang berita bohong ini adalah sebagai ketentuan umum (lex generali) yang dapat melengkapi ketentuaan yang ada dalam UU ITE, karena ketentuan yang ada dalam ITE adalah terbatas kepada informasi elektronik atau online.

Perlindungan hukum bagi korban yang telah dirugikan akibat penyebaran informasi hoax, selain pertanggungjawaban pidana maka korban yang telah dirugikan akibat penyebaran informasi hoax tersebut dapat mengajukan perlindungan hukum melalui gugatan perdata melalui gugatam wanprestasi atau perbuatan melawan hukum berdasarkan KUHPerdata maupun berdasarkan Pasal 38 UU Nomor 11 Tahun 2008 baik secara perseorangan maupun perwakilan apabila yang dirugikan masyarakat. Di samping itu selain penyelesaian gugatan perdata, para pihak dapat menyelesaikan sengketa melalui arbitrase, atau lembaga penyelesaian sengketa alternatif lainnya sesuai dengan ketentuan Peraturan Perundangundangan.

\section{$\underline{\text { Daftar Pustaka }}$}

\section{Buku}

Atmasasmita, Romli, 2000, Perbandingan Hukum Pidana, Mandar Maju, Bandung Fuady, Munir, 2002, Perbuatan Melawan Hukum, cet.1, CitraAditya Bakti, Bandung R., Ridwan, 2006, Hukum Administrasi Negara, Raja Grafindo Persada, Jakarta Istanto, Sugeng, 2007, Metode Penelitian, Raja Grafindo Persada, Jakarta Juditha, Christiany, 2018, Interaksi Komunikasi Hoax di Media Sosial serta Antisipasinya, Jurnal Pekommas, Vol. 3 No. 1

Mertha. I Ketut et. al., 2016, Buku Ajar Hukum Pidana Fakultas Hukum Universitas Udayana, Denpasar

Moegni Djojodirdjo, MA,2014, PerbuatanMelawan Hukum, cet.2, Pradnya Paramita, Jakarta Nasution, AZ, 2002, Hukum Perlindungan Konsumen, cet.2, Diapit Media, Jakarta Projodikoro, Wiryono, 1960, Perbuatan Melanggar Hukum,Sumur, Bandung, 1960) Soesilo. R, Kitab Undang-Undang Hukum Pidana (KUHP) Serta Komentar-Komentarnya Lengkap Pasal Demi PasaBogor 
Veno, Hendra, Laela Fakhriah, Eva 2019, Efektivitas Undang-Undang Republik Indonesia Nomor 19 Tabun 2016 Tentang Informasi Dan Transaksi Elektronik Terbadap Penanganan, Scientia Regend, Volume I, No1 Agustus

\section{Internet}

Wikipedia.(n.d.).Pemberitaanpalsu. https://mti.binus.ac.id/2017/07/03/penyalahgunaan-informasiberita-hoax-di-media$\underline{\text { sosial/ }}$

https://www.dosenpendidikan.co.id/analisis-isi/

https://metro.tempo.co/read/1372173/dituding-sebarkan-berita-bohong-musisi-anjidilaporkan-ke-polisi/full\&view=ok, Tempo, Senin, 3 Agustus 2020.

https://tekno.tempo.co/read/1372089/ramai-obat-herbal-covid-19-hadi-pranoto-initanggapan-kemristek $/$ full\&view $={ }_{\mathrm{Ok}}$

Respati, S. (2017, January 23). Mengapa Banyak Orang Mudah Percaya Berita "Hoax"? Kompas.com. Retrieved from

http://nasional.kompas.com/read/2017/01/23/18181951/mengapa.banyak.orang.mudah percaya.berita.hoax.

https://www.kbbi.web.id/

\section{Peraturan Perundang-undangan}

Undang-Undang Hukum Pidana (KUHP)

Undang-Undang Nomor 1 Tahun 1946 Tentang Peraturan Hukum Pidana

Undang-Undang Nomor 19 Tahun 2016 tentang Perubahan Atas Undang-Undang

Nomor 11 Tahun 2008 Tentang Informasi dan Transaksi Elektronik.

Undang-Undang Nomor 11 Tahun 2008 tentang Informasi dan Transaksi Elektronik 